\title{
Supplementation of sheep with increasing levels of crude protein: performance, animal behavior, and contamination and spread of nematode larvae in Brachiaria brizantha 'Xaraés' pasture ${ }^{1}$
}

\author{
Suplementação de ovinos com teores crescentes de proteína \\ bruta: desempenho, comportamento animal e a contaminação e \\ distribuição de larvas de nematódeos em pasto de capim-Xaraés
}

\author{
Rosane Cláudia Rodrigues ${ }^{2}$; Maria Antônia Melo3; Sâmara Stainy Cardoso Sanchês ${ }^{4}$; \\ Jocélio dos Santos Araújo ${ }^{2}$; Marcônio Martins Rodrigues ${ }^{5 *}$; \\ Ana Paula Ribeiro de Jesus ${ }^{2}$; Susan Emanuelly Pinheiro Amorin ${ }^{6}$; \\ Ricardo Alves Araújo7; Ivo Guilherme Ribeiro Araújo²; Henrique Nunes Parente ${ }^{2}$
}

\begin{abstract}
The aim of the present study was to evaluate the performance, animal behavior, and contamination and spread of nematode larvae of sheep supplemented with increasing levels of protein $(15,25$, and $35 \%)$ on Xaraés grass (Brachiaria brizantha 'Xaraés') pastures. Fifteen Santa Inês crossbred sheep, with an average age of approximately five months and average initial weight of $14.63 \mathrm{~kg}$, were used in the experiment. The feeding behavior (grazing and idle times) of animals was found to be influenced by the supplementation provided. The highest level of supplementation provided to the animals reduced their grazing time. The different levels of supplementation influenced the average daily gain and total final body weight gain of the sheep in Xaraés grass pastures. A significant difference was observed in the presence of parasitic larvae in the Xaraés grass pastures depending on different protein levels throughout the regrowth period. The number of larvae in feces was influenced by the protein content of the supplement, and varied throughout the pasture rest period. Animals showed a decrease in the number of larvae as their dietary crude protein (CP) content was increased. Supplementation with high protein, together with the action of vermifuge, increased the performance of sheep and reduced their parasite load and grazing time in Xaraés grass pastures.
\end{abstract}

Key words: Endoparasites. Larvae. Performance. Sheep.

\footnotetext{
1 Trabalho de conclusão do Curso de Zootecnia da segunda autora.

2 Profs. Drs., Curso de Zootecnia, Universidade Federal do Maranhão, UFMA, Chapadinha, MA, Brasil. E-mail: rosanerodrig@, gmail.com; jocelios@yahoo.com.br; btpaular@hotmail.com; igravet@hotmail.com; hnparente@hotmail.com

3 Discente do Curso de Zootecnia, UFMA, Chapadinha, MA, Brasil. E-mail: maria@yahoo.com.br

${ }^{4}$ Discente do Curso de Mestrado do Programa de Pós-Graduação em Ciência Animal, UFMA, Chapadinha, MA, Brasil. E-mail: samara-sanches12@hotmail.com

${ }^{5}$ Bolsista DCR FAPEMA/CNPq, UFMA, Chapadinha, MA, Brasil. E-mail: marnunes07@yahoo.com.br

${ }^{6}$ Discente do Curso de Mestrado do Programa de Pós-Graduação em Ciência Animal, Universidade Federal do Piauí, UFPI, Teresina, PI, Brasil. E-mail: emanuelly_p.amorim@yahoo.com.br

7 Discente do Curso de Doutorado do Programa de Pós-Graduação em Zootecnia, Universidade Federal do Ceará, UFC, Fortaleza, CE, Brasil. E-mail: ricardo_zoo@hotmail.com

* Autthor for correspondence
} 


\title{
Resumo
}

\begin{abstract}
Objetivou-se avaliar o desempenho, comportamento animal e a contaminação e distribuição de larvas de nematódeos de ovinos suplementados com níveis crescentes de proteína em pasto de capim-Xaraés. O delineamento experimental foi inteiramente casualizado com três tratamentos (níveis de proteína 15, 25 e 35\%). Foram utilizados 15 ovinos mestiços da raça Santa Inês, com aproximadamente cinco meses de idade e peso médio inicial de 14,63 kg. As atividades de comportamento ingestivo (tempo de pastejo e ócio) dos animais foram influenciadas pela suplementação fornecida. O maior nível de suplementação fornecido aos animais reduziu o tempo de pastejo. Os diferentes níveis de suplementações fornecida aos animais influenciou o ganho médio diário e o ganho de peso total final corporal, dos ovinos mantidos em pastos de capim-Xaraés. Observou-se influência das suplementações sobre a presença e número de larvas no pasto. Os animais apresentaram redução do número de larvas com o aumento do teor de PB na dieta. A suplementação com alto teor proteico, juntamente com a ação do vermífugo, aumentou o desempenho dos ovinos e reduziu a carga parasitária e o tempo de pastejo dos animais mantidos em capim-Xaraés, contudo, há a necessidade de uma análise econômica, visto que o alto teor de compostos nitrogenados na dieta pode tornar o sistema inviável.
\end{abstract}

Palavras-chave: Capim-Xaraés. Endoparasitos. Larvas. Ovinos.

\section{Introduction}

Sheep breeding in Brazil is mainly conducted in pastures, resulting in lower animal production costs and increased competitiveness. However, limited studies have been conducted on the forage potential of sheep, and some gaps related to sheep breeding in pastures are still observed. Several doubts about how to choose the proper forage species and how to treat problems caused by gastro-intestinal parasitosis, which is currently the main sanitation problem affecting sheep in pastures, need to be addressed (SILVA SOBRINHO, 2001).

These doubts arise because of the different grazing habits of sheep as compared to bovine; they are much more selective and prefer shorter pastures (GONÇALVES et al., 2009). This difference in grazing habits affects the selection and management of proper forage species.

In addition, lambs, like any young animals, present an elevated susceptibility to parasite infections, especially by Haemonchus contortus and Trichostrongylus colubriformes, which are the main nematode parasites of sheep (ALMEIDA et al., 2010). These nematodes adversely affect pasture breeding, and also reduce the productive performance of sheep.
Thus, it is important to perform a proper herd and pasture management in order to avoid environments containing a high parasite load, as usually is done in commercial pastures through strategies for controlling herd parasitism and preventing environment contamination by rational medicine administration. Other strategies, such as protein supplementation in animal feeding, should be used for parasite control. Besides improving the animal production performance, supplementation also contributes in improving host immune capacity and response against gastro-intestinal parasites (PHENGVICHITH; LEDIN, 2007; BARONI et al., 2010).

Nogueira et al. (2008) observed reduction in eggs per gram of feces (EPG) in sheep fed with different protein sources (urea, and soybean and cottonseed meals), when compared with animals fed only with pasture. This effect was observed because animals under supplementation exhibit better immune response to nematode infections and lower consumption of infected forage.

Gazda et al. (2009) reported that limited data is available on the survival of infecting parasite larvae in pastures and the description of their population in subtropical regions throughout the year and that it depends on several factors, such as regional climate 
conditions, seasonality, forage species, and sheep feeding habits.

Considering sheep preferences for shortmedium grasses over tussock grasses, the creepingtype (decumbent or stoloniferous) grasses are most appropriate for sheep breeding (PALHANO et al., 2007).

However, some researchers have observed that tussock grasses provide an advantage by allowing a better sunlight penetration to their base, and because they are upright, they do not completely cover the soil's surface, thus promoting the exposition of helminth larvae and eggs to weather (sunlight and rainfall). This fact has contributed to an increase in the use of tussock species for sheep breeding. As creeping-type grasses completely cover the soil surface, they contribute to increasing the larval lifetime in pastures (SILVA SOBRINHO, 2001).

Assuming that forage species, diet, and climate conditions of each region affect sheep infection by nematode larvae, and that the pasture structure and feeding behavior of sheep affect their performance in pasture conditions, the aim of this study was to evaluate the performance, animal behavior, and contamination and distribution of nematode larvae in sheep under supplementation using increasing protein levels in Brachiaria brizantha 'Xaraés' pastures.

\section{Materials and Methods}

The experimentwas conductedintheForageCrops Sector, in a property of the Center for Agriculture and Environment Sciences of the Federal University of Maranhão, Chapadinha, Lower Parnaíba Region,

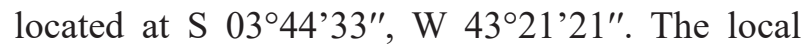
soil was categorized as Yellow Oxisol (EMBRAPA, 1999). Chapadinha presents a humid tropical climate, in which the rainy season occurs between December and May, while the dry season occurs between July and November (SELBACH; LEITE,
2008). The average temperature throughout the year is over $27^{\circ} \mathrm{C}$ (GOVERNO DO ESTADO DO MARANHAO, 2002), presenting $38^{\circ} \mathrm{C}$ maximum and $21^{\circ} \mathrm{C}$ minimum, and an average annual rainfall between 1,200 and 1,400 mm (SELBACH; LEITE, 2008). During the experiment period, the average temperature varied between 23.4 and $35.3^{\circ} \mathrm{C}$. The soil in the experimental area presented the following chemical characteristics: $\mathrm{pH}, 4.2 ; \mathrm{OM}, 19.0 \mathrm{~g} \mathrm{dm}^{-3}$; $\mathrm{P}, 5.0 \mathrm{mg} \mathrm{dm}^{-3}$; S, $9.0 \mathrm{mg} \mathrm{dm}^{-3} ; \mathrm{K}, 0.4 \mathrm{mmol} \mathrm{dm}^{-3}$; $\mathrm{Ca}, 0.5 \mathrm{mmol} \mathrm{dm}{ }^{-3} ; \mathrm{Mg}, 2.0 \mathrm{mmol} \mathrm{dm}^{-3} ; \mathrm{H}+\mathrm{Al}$, $29 \mathrm{mmol} \mathrm{dm}^{-3}$; $\mathrm{Al}, 8.0 \mathrm{mmol} \mathrm{dm}^{-3}$; cation exchange capacity (CEC), $36 \mathrm{mmol} \mathrm{dm}^{-3}$; base saturation (BS), $7.4 \mathrm{mmol} \mathrm{dm}^{-3}$; V, $20 \%$;, 52 ; B, $1.43 \mathrm{mg}$ $\mathrm{dm}^{-3}$; Cu, $0.2 \mathrm{mg} \mathrm{dm}^{-3}$; Fe, $55.0 \mathrm{mg} \mathrm{dm}^{-3}$; Mn, 0.4 $\mathrm{mg} \mathrm{dm}{ }^{-3} ; \mathrm{Zn}, 0.3 \mathrm{mg} \mathrm{dm}^{-}$.

The total area was approximately 1 ha, and was divided into $12 \times 840 \mathrm{~m}^{2}$ plots, which were further subdivided into $5 \times 180 \mathrm{~m}^{2}$ plots, in which animals were bred. The experimental area was surrounded by barbed wire fences, and its subdivisions had wire fences installed in their internal borders. Each plot had its own feeders, drinkers, and $8.0 \mathrm{~m}^{2}$ shades (25\% transparency).

Soil preparation, corrective actions, and sowing were performed in March 2011. Fertilization was performed according to the results of soil analysis and requirements of forage species. Pasture maintenance was performed between April and October 2011. The same amount of seeds was used for all plots.

The experimental period was scheduled from October 30, 2011 to January 7, 2012. A total of fifteen sheep with the following characteristics were bred: unblemished, crossbred, approximately 15 years old, and initially weighing $14.63 \pm 0.045$ $\mathrm{kg}$ (live weight; LW).

Animals were kept in Uruchloa brizantha 'Xaraés' pastures between $07 \mathrm{~h} 00$ and $17 \mathrm{~h} 15$, with full access to water and artificial shade. At the end of the day, they were housed in individual pens, where water and mineral salt were offered ad libitum. 
Forage (three samples per plot) was offered using a $0.50-\mathrm{m}^{2}$ PVC square-structure. After determining the wet weight of each forage sample in the laboratory, it was divided into three parts-dead plant material, stem, and leaves. Subsequently, these parts were dried until they reached a constant weight, using a forced-air oven at $55^{\circ} \mathrm{C}$. The leaf/stem (leaf weight/stem weight) ratio was calculated for each sample.

For food and diet samples, the following parameters were determined: dry matter (DM), mineral matter (MM), and crude protein (CP) (AOAC, 2012). The determination of the neutral detergent fiber (NDF) was performed adapting the method proposed by Van Soest et al. (1991). The value of total digestible nutrients (TDN) was obtained using equations described by Cappelle et al. (2001).

Protein supplementation with a quantity calculated for $1 \%$ of the body weight was provided to sheep at $08 \mathrm{~h} 00$ daily (Table 1 ). The animals were weighed on a weekly basis and the protein supplementation was accordingly adjusted. Four supplementation levels were applied to sheep under rotational grazing using Urochloa Brizantha 'Xaraés'. The CP levels of 15.7, 25.7, and $35.6 \%$ were classified as low, medium, and high supplementation levels, respectively, with an estimated daily consumption capability of $3.5 \%$ DM.

Table 1. Chemical-bromatological composition (\%) of protein supplementation ingredients.

\begin{tabular}{lccc}
\hline \multirow{2}{*}{ Ingredients } & \multicolumn{3}{c}{ Treatments $^{1}$} \\
\cline { 2 - 4 } & LP & MP & HP \\
\hline Ground corn & 85.00 & 58.00 & 31.00 \\
Soybean meal & 10.00 & 37.00 & 64.00 \\
Mineral salt + Ammonium chloride & 4.00 & 4.00 & 4.00 \\
Urea + Sulfate & 1.00 & 1.00 & 1.00 \\
\hline Diet's chemical-bromatological composition & & & \\
Dry matter & 89.30 & 89.30 & 89.40 \\
Crude protein & 15.70 & 25.66 & 35.55 \\
NDF & 21.26 & 21.96 & 22.66 \\
Total digestible nutrients & 78.87 & 78.47 & 78.07 \\
\hline
\end{tabular}

${ }^{1}$ LP: Low-protein supplement; MP: Medium-protein concentrate; HP: High-protein supplement; NDF: neutral detergent fiber.

The experimental period was 68 days, of which 7 days were used for the supplementation and grazing acclimation of sheep. Before initiating the experiment, the parasite load of each animal was evaluated on the basis of its clinical symptoms, EPG (eggs per gram of feces) count, and Famacha ${ }^{\circledR}$ scoring technique, followed by the administration of vermifuges. Based on our laboratory results, the anthelmintic medication containing the following active ingredients was administered: nitroxynil (1.0 $\left.\mathrm{ml} \mathrm{kg}{ }^{-1} \mathrm{LW}\right)$ and moxidectin $\left(2.0 \mathrm{ml} \mathrm{kg}{ }^{-1} \mathrm{LW}\right)$.
Daily animal weight gain was determined by weighing each animal once every 7-days period until slaughtering and after a 14-h solid fasting. The average daily gain (ADG) was calculated as follows: $\mathrm{ADG}=$ (weight in the end of cycle -weight in the beginning of the cycle) / time.

The animal behavior was evaluated on three dates during the experimental period (start, middle, and end). The following behavioral activities were observed every 15 minutes: time spent in grazing $(\mathrm{G})$, feeder supplementation (S), idle time in shade 
(ITS), idle time under sunlight (IUS), drinking water (W), and movement (M) (BARROS et al., 2007).

For evaluating pasture contamination, the forage samples were collected for counting the infecting larvae using a $0.0625-\mathrm{m}^{2}(25 \times 25 \mathrm{~cm})$ frame. The samples were properly packed in plastic bags and refrigerated, and then processed in the Veterinary Parasitology Laboratory according to the method described by Taylor (1939) and Raynauld and Gruner (1982). The samples were grouped into grazed and ungrazed types. The grazed samples accounted for approximately $50 \%$ of the upper portion of plants (CARVALHO, 1997). The infecting larvae were counted and the number of larvae per gram of dry matter ( $\left.\mathrm{L} \mathrm{g}^{-1} \mathrm{DM}\right)$ was calculated.

Sample collection was performed during the milder morning hours (07h30-10h00). Camuset (1994) has reported increased larval movement in the upper portions of plants during these hours (phototropism).

Coproparasitological tests were performed on a biweekly basis using the modified methods proposed by Gordon and Whitlock (1939) and Willis (1921). Feces were collected daily, directly from the rectum of each animal. The treatment criteria included clinical symptoms and an EPG count of 500 (STEVALE et al., 2016).

The data were subjected to variance analysis, and a mean comparison was performed using Student's t-test and Tukey's test at 5\% probability using InfoStat ${ }^{\circledR}$ software (2004). Data related to the number of larvae and EPG presented a non-normal distribution, thus a nonparametric analysis was performed using Kruskal-Wallis test.

\section{Results and Discussion}

Data related to pasture structure during pre and post-grazing periods, depending on the protein levels, are presented in Table 2. The amount of leaves, stems, and dead plant material did not differ $(\mathrm{P}<0.05)$ among treatments (LP, MP, and HP) during pre and post-pasture periods.

Table 2. Amount of leaves, stem, leaf/stem ratio, dead plant material, and total forage weight available for animals in Xaraés grass pasture receiving different levels of protein supplementation.

\begin{tabular}{|c|c|c|c|}
\hline & \multicolumn{3}{|c|}{ Treatments } \\
\hline & $\mathrm{LP}^{1}$ & $\mathrm{MP}^{2}$ & $\mathrm{HP}^{3}$ \\
\hline \multicolumn{4}{|c|}{ Leaves weight $(\mathrm{g})$} \\
\hline Pre-grazing & $73.59^{\mathrm{Aa}}$ & $65.31^{\mathrm{Aa}}$ & $69.05^{\mathrm{Aa}}$ \\
\hline Post-grazing & $16.98^{\mathrm{Ab}}$ & $21.33^{\mathrm{Ab}}$ & $23.69^{\mathrm{Ab}}$ \\
\hline \multicolumn{4}{|c|}{ Stem weight $(\mathrm{g})$} \\
\hline Pre-grazing & $46.87^{\mathrm{Aa}}$ & $41.10^{\mathrm{Aa}}$ & $54.24^{\mathrm{Aa}}$ \\
\hline Post-grazing & $34.13^{\mathrm{Aa}}$ & $32.27^{\mathrm{Aa}}$ & $42.47^{\mathrm{Aa}}$ \\
\hline \multicolumn{4}{|c|}{ Leaf/stem ratio } \\
\hline Pre-grazing & $1.29^{\mathrm{Aa}}$ & $1.65^{\mathrm{Aa}}$ & $1.00^{\mathrm{Aa}}$ \\
\hline Post-grazing & $0.50^{\mathrm{Ab}}$ & $0.50^{\mathrm{Ab}}$ & $0.69^{\mathrm{Aa}}$ \\
\hline \multicolumn{4}{|c|}{ Dead plant material weight $(\mathrm{g})$} \\
\hline Pre-grazing & $52.90^{\mathrm{Aa}}$ & $45.07^{\mathrm{Aa}}$ & $38.71^{\mathrm{Aa}}$ \\
\hline Post-grazing & $55.10^{\mathrm{Aa}}$ & $34.45^{\mathrm{Aa}}$ & $43.52^{\mathrm{Aa}}$ \\
\hline \multicolumn{4}{|c|}{ Total forage weight available (g) } \\
\hline Pre-grazing & 173.36 & 151.48 & 162.00 \\
\hline Post-grazing & 106.21 & 88.05 & 109.68 \\
\hline
\end{tabular}

${ }^{1} \mathrm{LP}$ : Low-protein supplement; ${ }^{2} \mathrm{MP}$ : Medium-protein concentrate; ${ }^{3} \mathrm{HP}$ : High-protein supplement.

Means followed by the same letter-capitalized in rows and non-capitalized in columns-did not present differences in Student's t-test ( $\mathrm{P}>0.05$ ). 
Higher leaf consumption probably occurred in the pastures with low and medium levels of crude protein treatment, which might be explained by the lower nutrient availability in such pastures. Thus, the animals probably presented a higher ingestion rate in order to meet their nutritional requirements. This inference was made by observing longer grazing periods and because sheep prefer eating leaves (Table 3). Oliveira et al. (2011) observed a decrease in forage consumption by sheep supplemented with different protein sources (urea and soybean and cottonseed meals), when compared with the pasture-fed animals; they reported that this occurred due to the substitution consumption of supplements for pasture. An increase in the daily grazing time of animals is a behavioral strategy for compensating reduction in nutrient consumption during limiting conditions in pastures with unfavorable structural and qualitative characteristics.

Table 3. Behavioral activities of pasture-sheep receiving supplementation with different crude protein levels.

\begin{tabular}{lcccc}
\hline \multirow{2}{*}{ Activities (hours) } & \multicolumn{3}{c}{ Treatments ${ }^{1,2}$} & \multirow{2}{*}{ CV } \\
\cline { 2 - 4 } & $\mathrm{LP}(15 \%)$ & $\mathrm{MP}(25 \%)$ & $\mathrm{HP}(35 \%)$ & $6.86^{\mathrm{B}}$ \\
\hline Grazing time & $7.01^{\mathrm{AB}}$ & $7.52^{\mathrm{A}}$ & $2.47^{\mathrm{B}}$ & 13.14 \\
Idle in shade & $3.0^{\mathrm{A}}$ & $2.18^{\mathrm{B}}$ & $0.94^{\mathrm{A}}$ & 30.61 \\
Idle under sunlight & $0.57^{\mathrm{B}}$ & $1.0^{\mathrm{A}}$ & $1.25^{\mathrm{A}}$ & 27.79 \\
Moving & $1.14^{\mathrm{A}}$ & $0.93^{\mathrm{A}}$ & $0.52^{\mathrm{A}}$ & 10.13 \\
Feeder supplementation & $0.55^{\mathrm{A}}$ & $0.50^{\mathrm{A}}$ & $0.56^{\mathrm{A}}$ & 38.44 \\
Water ingestion & $0.63^{\mathrm{A}}$ & $0.61^{\mathrm{A}}$ & \\
\hline
\end{tabular}

${ }^{1} \mathrm{LP}$ : Low-protein supplement; ${ }^{2} \mathrm{MP}$ : Medium-protein supplement; ${ }^{3} \mathrm{HP}$ : High-protein supplement.

${ }^{2}$ Means followed by the same letter in lines do not present differences in Student's t-test $(\mathrm{P}>0.05)$.

Lower values of pasture weight result from the reduced forage growth during dry season as well as selective feeding by sheep, since they prefer to consume green leaves, which are the most nutritious part of a plant. Higher leaf/stem ratio was observed during the pre-grazing period for all treatments, which indicated that the pastures presented enough leaves for selective grazing (Table 2).

No supplementation effects were observed $(\mathrm{P}>0.05)$ on the amount of leaves and stem during pre and post-grazing periods. However, significant differences were observed in the amount of leaves between pre and post-pasture periods, which confirmed the preference of sheep for this plant part. No difference was observed in diets based on the amount of pasture stems, probably resulting from the pasture homogeneity and adequate quantity of leaves during the evaluation period, since the stocking rate was calculated on the basis of the forage offered.

Animal feeding behavior (grazing and idle times) was influenced by supplementation (Table 3). Significant differences were observed in grazing and idle activities for different supplementation levels. Animals that received 35\% CP supplementation grazed for shorter periods than those that received $25 \%$ 'in concentrate' CP supplementation. This might be related to the relatively higher nutrient availability, since low-quality forage usage optimization for ruminants could be reached using supplementary nutrients, especially nitrogen compounds (KÖSTER et al., 1996).

Champion et al. (2004) reported that sheep normally graze for approximately 10 hours per day, a value above the average grazing period observed in this study $(7.13 \mathrm{~h})$. However, it is worth noting that 
the animals adopted the restricted grazing method, which is widely used in the Brazilian Northeastern region, where animals are kept in a pen during the evening and released into a pasture by dawn. Parente et al. (2007) evaluated the feeding behavior of sheep under restricted grazing conditions and reported an average grazing period of $6.95 \mathrm{~h}$, which is similar to our findings. Costa et al. (2015) observed an average sheep grazing period of $7.3 \mathrm{~h}$ in silvopastoral systems composed of leucaena and grass.

A significant difference was observed in the idle time of sheep in shade and under sunlight (Table 3). Animals that received relatively lower levels (15\%) of protein concentrate presented longer idle times in shade. The opposite was observed for idle times of animals under sunlight (lower than those observed in other treatments).

No difference was observed between the treatments for the following variables: moving, feeder supplementation and water ingestion $(\mathrm{P}>0.05)$. As the plot areas were small, it was not necessary for the pasture animals to move frequently, because their nutritional needs were met by the food provided by pasture and supplementation.

Protein supplementation influenced $(\mathrm{P}>0.05)$ the average daily (weight) gain and the total body weight gain of the sheep bred in Xaraés pasture (Table 4). The highest supplementation level (35\%) resulted in the best performance with a total body weight gain of $0.133 \mathrm{~kg} \mathrm{day}^{-1}$, which was superior to those obtained with $15\left(0.103 \mathrm{~kg} \mathrm{day}^{-1}\right)$ and $25 \%$ $\left(0.107 \mathrm{~kg} \mathrm{day}^{-1}\right)$ protein supplementation. These values are above those reported by Manera et al. (2014), who evaluated the performance of sheep supplemented with concentrates that contained fruit processing co-products (acerola, guava, and grape) and obtained body weight gain of $0.53,0.65$, and $0.49 \mathrm{~kg} \mathrm{day}^{-1}$, respectively.

Table 4. Initial sheep weights, average weight gain $\left(\mathrm{kg} \mathrm{day}^{-1}\right)$, and total number of lambs receiving supplementation with different protein levels in Xaraés pastures during the experiment period.

\begin{tabular}{ccccccc}
\hline \multirow{2}{*}{ Variable } & \multicolumn{3}{c}{ CP Level } & \multirow{2}{*}{ CV $(\%)^{*}$} & \multirow{2}{*}{ SEM $^{* *}$} & P-value \\
\cline { 2 - 4 } \cline { 2 - 4 } & Low & Medium & High & & \\
\hline IW & $14.64 \pm 3.12 \mathrm{a}$ & $14.68 \pm 1.79 \mathrm{a}$ & $14.57 \pm 0.91 \mathrm{a}$ & 14.65 & 0.512 & 0.9965 \\
AWG & $0.103 \pm 0.01 \mathrm{~b}$ & $0.107 \pm 0.2 \mathrm{~b}$ & $0.133 \pm 0.01 \mathrm{a}$ & 12.89 & 0.005 & 0.0221 \\
TWG & $7.07 \pm 0.85 \mathrm{~b}$ & $7.30 \pm 1.25 \mathrm{~b}$ & $9.07 \pm 0.85 \mathrm{a}$ & 12.89 & 0.353 & 0.0218 \\
\hline
\end{tabular}

Means followed by same letters do not differ, according to Duncan's test $(\mathrm{P}>0.05)$.

*Coefficient of Variation

**Standard Error of the Mean.

The average and total weight gain obtained with $35 \%$ CP supplementation were 22.6 and $19.5 \%$ more than those obtained with 15 and $25 \%$ CP diets. (Table 4). This fact might be related to a relatively higher nutrient availability associated with a higher supplement level, since the pasture was homogeneous during the experimental period.

Different protein levels affected parasite infection level $(\mathrm{P}<0.05)$ during the experimental period (Table 5). No difference was observed in EPG of sheep treated with different protein levels until day 21 probably because they were still under the effect of vermifuge administered at the beginning of the experiment. From day 28to 42, an effect of higher protein levels over EPG reduction was observed, indicating that the medium and high protein concentrations led to the reduction of nematodes in the gastro-intestinal tract of these 
animals. These findings are similar to the data obtained by Veloso et al. (2004), who studied the effect of different protein levels on sheep, and Igarashi et al. (2013), who studied the effect of protein supplement in association with neem oil and dry leaves (Azadirachta indica) on sheep. After day 49 , an increase in the dietary protein levels did not affect EPG and resulted in a higher parasite load probably because the vermifuge was administered only at the beginning of the experiment. The literature reports that the properly fed animals present a higher resistance against parasites than the animals with nutritional deficiency, and our findings indicate that animals receiving 35\% CP diets showed an increase in parasite load after 49 days of protein supplementation, and that the same animals obtained an average daily gain of $0.133 \mathrm{~kg}$ day $^{-1}$ (Table 4).

Table 5. Number of helminth eggs per gram of feces (EPG) in lambs receiving supplementation with different protein levels in Xaraés pastures during the experimental period.

\begin{tabular}{cccc}
\hline \multirow{2}{*}{$\begin{array}{c}\text { Period } \\
\text { (days) }\end{array}$} & \multicolumn{3}{c}{ Protein level (\%) } \\
\cline { 2 - 4 } & 15 & 25 & 35 \\
\hline 7 & $1150^{\mathrm{Aabc}}$ & $350^{\mathrm{Abcde}}$ & $600^{\mathrm{Aabc}}$ \\
14 & $1265^{\mathrm{Aabc}}$ & $300^{\mathrm{Acde}}$ & $150^{\mathrm{Abc}}$ \\
21 & $200^{\mathrm{Ac}}$ & $600^{\mathrm{Abcde}}$ & $150^{\mathrm{Abc}}$ \\
28 & $2650^{\mathrm{Aa}}$ & $0^{\mathrm{Be}}$ & $300^{\mathrm{Bbc}}$ \\
35 & $550^{\mathrm{Aabc}}$ & $600^{\mathrm{Abcde}}$ & $950^{\mathrm{Aabc}}$ \\
42 & $2650^{\mathrm{Aa}}$ & $500^{\mathrm{Bde}}$ & $300^{\mathrm{Bc}}$ \\
49 & $350^{\mathrm{Abc}}$ & $2150^{\mathrm{Aabc}}$ & $1300^{\mathrm{Aa}}$ \\
56 & $950^{\mathrm{Aabc}}$ & $1550^{\mathrm{Aab}}$ & $1300^{\mathrm{Aab}}$ \\
73 & $1750^{\mathrm{Aab}}$ & $3500^{\mathrm{Aa}}$ & $1900^{\mathrm{Aa}}$ \\
80 & $2350^{\mathrm{Aa}}$ & $4900^{\mathrm{Aa}}$ & $2250^{\mathrm{Aa}}$ \\
\hline
\end{tabular}

Medians followed by capitalized letters in lines and noncapitalized letter in columns do not differ among themselves, according to Student's t-test $(\mathrm{P}<0.05)$.

Studies conducted by Wallace et al. (1999) and Haile et al. (2002) reported the beneficial effects of protein supplementation in the diet of sheep with endoparasites-improvement in the infection- resistance capacity of host and decreased parasite egg production in feces. However, it is important to maintain a balance between nutrition and health, as protein level increases might not only be beneficial for parasite control, but could also lead to physiological problems, especially kidney and liver overload, due to the large amount of nitrogenous compounds in them. In addition, it might lead to an increase in the production costs of animals, since investments in nutritional planning might present an obstacle to the cost/benefit ratio of a pasture.

In animals that received a low-protein supplementation $(15 \% \mathrm{CP})$, the lowest EPG count was observed on day 21 and the highest EPG count (a $91 \%$ increase) was observed on day 80 of the experiment. Animals that received a medium-protein $\operatorname{diet}(25 \% \mathrm{CP})$ presented the lowest and highest EPG counts on the 28th and 80th days, respectively. The medium-protein treatment presented the highest EPG count when compared to other protein levels on the 80th day. Animals that received high protein levels $(35 \% \mathrm{CP})$ presented the lowest parasite load from the 14th to 42 nd day, indicating that animals fed by grazing-even when supplemented-require greater monitoring from the 42nd day onward, owing to an increase in parasite load after this period. Until the end of the experiment (68 days), the animals supplemented with $35 \% \mathrm{CP}$ presented a superior performance, when compared with animals fed with 15 and 25\% CP diets (Table 4).

A constant presence $(\mathrm{P}<0.05)$ of parasite larvae was observed in Xaraés pastures during the resprout stage (Table 6). During the pasture rest period, the plots occupied by animals supplemented with $15 \%$ $\mathrm{CP}$ presented the lowest number of larvae, when compared with the plots occupied by animals fed with $25 \% \mathrm{CP}$ diets on day zero. On the other hand, the pastures occupied by animals fed with $25 \%$ $\mathrm{CP}$ diet presented the highest number of larvae on day zero, being 99.4 and $84.2 \%$ higher than the animals that received 15 and $35 \% \mathrm{CP}$, respectively, indicating an increase in pasture contamination. No difference was observed in the number of larvae 
associated with different protein levels in plots on the 7 th and 21 st day after removing the animals from them. However, on day 42, the treatment with $25 \%$ $\mathrm{CP}$ presented the lowest number of larvae, when compared to the other treatments. These results are consistent with the reduction in the number of fecal larvae ( $P>0.05$; Table 6$)$; the medium-protein supplementation presented a value 7.0 and 5.5 times lower than those of the low- and high-protein treatments, respectively, on the 42nd day.

Table 6. Helminth larvae count ( $\left.\mathrm{L} \mathrm{g}^{-1} \mathrm{DM}\right)$ found in plants, soil, and feces, in pastures occupied by lambs receiving supplementation with different protein levels during the pasture rest period.

\begin{tabular}{|c|c|c|c|}
\hline \multirow{2}{*}{ Rest period } & \multicolumn{3}{|c|}{ Treatments } \\
\hline & 15 & 25 & 35 \\
\hline \multicolumn{4}{|c|}{ Larvae count in plants $\left(\mathrm{L} \mathrm{g}^{-1} \mathrm{DM}\right)$} \\
\hline 0 days & $1^{\mathrm{Bb}}$ & $171^{\mathrm{Aa}}$ & $27^{\mathrm{ABab}}$ \\
\hline 7 days & $164^{\mathrm{Aa}}$ & $180^{\mathrm{Aa}}$ & $59^{\text {Aab }}$ \\
\hline 21 days & $91^{\mathrm{Aa}}$ & $55^{\mathrm{Aab}}$ & $14^{\mathrm{Ab}}$ \\
\hline 42 days & $125^{\mathrm{Aa}}$ & $16^{\mathrm{Bb}}$ & $80^{\mathrm{Aa}}$ \\
\hline \multicolumn{4}{|c|}{ Larvae count in soil $\left(\mathrm{L} \mathrm{g}^{-1} \mathrm{DM}\right)$} \\
\hline 0 days & $0^{\mathrm{Bb}}$ & $10^{\mathrm{Aa}}$ & $3^{\mathrm{Bba}}$ \\
\hline 7 days & $52^{\mathrm{Aa}}$ & $10^{\mathrm{Ba}}$ & $22^{\mathrm{Bba}}$ \\
\hline 21 days & $36^{\mathrm{Aa}}$ & $26^{\mathrm{Aa}}$ & $4^{\mathrm{Aa}}$ \\
\hline 42 days & $22^{\mathrm{Aa}}$ & $32^{\mathrm{Aa}}$ & $13^{\mathrm{Aa}}$ \\
\hline \multicolumn{4}{|c|}{ Larvae count in feces $\left(\mathrm{L} \mathrm{g}^{-1} \mathrm{DM}\right)$} \\
\hline 0 days & $507^{\mathrm{Aa}}$ & $97^{\mathrm{Aa}}$ & $157^{\text {Aa }}$ \\
\hline 7 days & $149^{\text {Aa }}$ & $36^{\mathrm{ABa}}$ & $13^{\mathrm{Bb}}$ \\
\hline 21 days & $74^{\mathrm{Aa}}$ & $18^{\mathrm{Aa}}$ & $14^{\mathrm{Ab}}$ \\
\hline 42 days & $63^{\mathrm{Aa}}$ & $9^{\mathrm{Aa}}$ & $50^{\mathrm{Aab}}$ \\
\hline
\end{tabular}

Means followed by capitalized letters in lines and non-capitalized letter in columns do not differ among themselves in accordance with Student's t-test $(\mathrm{p}<0.05)$.

The numbers of larvae were counted after removing of animals from the experimental plots. We observed that the lowest larvae count occurred immediately after the removal of animals fed with $15 \%$ CP diets. For 25 and $35 \% \mathrm{CP}$ treatments, the lowest larvae count occurred on the $42 \mathrm{nd}$ and $21 \mathrm{st}$ days, respectively.

Protein levels affected the larval contamination of soil $(\mathrm{P}<0.05)$ (Table 6). However, the treatment with $15 \% \mathrm{CP}$ showed no effect $(\mathrm{P}>0.05)$ on the larval count of the soil, showing no larval presence during the first pasture rest day. On day zero, the lowest larval count occurred in the soil with $15 \% \mathrm{CP}$ treatment, which was similar to the soil with $35 \%$
$\mathrm{CP}$ treatment. The highest larval count occurred in the soil with $25 \% \mathrm{CP}$ treatment. However, on day 7 , the lowest larval count occurred in the soil with $25 \%$ CP treatment, which was similar to that with $35 \% \mathrm{CP}$ treatment. These results are consistent with the number of larvae present in grass.

On day zero of the pasture rest period, the lowest helminth numbers were observed in pastures that received $15 \% \mathrm{CP}$ supplementation; however, this infestation behavior changed on day 7 , due to the fact that soil with $25 \% \mathrm{CP}$-supplemented animals presented the lowest parasite infestation during this period. From day 21 to 42 of the pasture rest period, no effects of supplementation were observed on the 
larval count of the pasture soil $(\mathrm{P}>0.05)$.

The number of larvae in feces was affected $(\mathrm{P}<0.05)$ by the supplement protein-level and pasture rest period. A significant effect was observed among the protein levels $(\mathrm{P}<0.05)$ only on the 7 th day, when $35 \%$ CP treatment presented a relatively lower number of larvae in feces, in a way similar to the $25 \% \mathrm{CP}$ treatment. No effects of protein supplementation diets $(\mathrm{P}>0.05)$ were observed on the fecal-larvae count during the pasture rest period.

During the pasture rest period, the effects of protein diets $(\mathrm{P}<0.05)$ were observed on the fecallarvae count only occurred in pastures with $35 \%$ CP treatment. Nevertheless, a reduction in larval counts was observed in all pastures (for all protein levels) the 7th day onward after the removal of animals from the plots. The highest larval count was observed immediately after the removal of animals from the pastures.

\section{Conclusion}

High-protein supplementation combined with vermifuge administration increased the performance and reduced the parasite load and grazing time for sheep bred in Xaraés pasture. However, this technique should be recommended after conducting an economic feasibility analysis for the adopted protein level as the majority of nitrogen compounds can be excreted and their effects on animal performance can be reduced.

\section{Acknowledgements}

We would like to thank all members of the FOPAMA group (Forragicultura e Pastagens no Maranhão; Forage \& Pastures in Maranhão), and Centro de Ciências Agrárias e Ambientais/ Universidade Federal do Maranhão for assistance during the experiment. We also thank the Brazilian Northeastern Bank (Banco do Nordeste do Brasil) for funding this research.

\section{References}

ALMEIDA, F. A.; GARCIA, K. C.; TORGERSON, P. R.; AMARANTE, A. F. Multiple resistance to anthelmintics by Haemonchus contortus and Trichostrongylus colubriformes in sheep in Brazil. Parasitology Internacional, Amsterdam, v. 59, n. 4, p. 622-625, 2010.

ASSOCIATION OF OFFICIAL ANALYTICAL CHEMISTS - AOAC. Official methods of analysis. $19^{\text {th }}$ ed. Gaithersburg: AOAC International, 2012.

BARONI, C. E. S.; LANA, R. P.; MANCIO, A. B.; MENDONÇA, B. P. C.; LEÃO, M. I.; SVERZUT, C. B. Consumo e digestibilidade de nutrientes em novilhos suplementados e terminados em pasto, na seca. Arquivo Brasileiro de Medicina Veterinária e Zootecnia, Belo Horizonte, v. 62, n. 2, p. 365-372, 2010.

BARROS, C. S.; DITTRICH, J. R.; ROCHA, C.; SILVA, C. J. A.; ROCHA, F. M. P.; MONTEIRO, A. L. G.; BRATTI, L. F. S.; SILVA, A. L. P. Comportamento de caprinos em pastos de Brachiaria hibrida cv. mulato. Revista da Faculdade de Veterinária, Zootecnia e Agronomia de Uruguaina, Uruguaiana, v. 14, n. 2, p. 187-206, 2007.

CAMUSET, P. Epidemiologie des strongyloses: parasitisme des bovines. Paris: Bulletin des GTV, 1994. p. 27-42.

CAPPELLE, E. R.; VALADARES FILHO, S. C.; SILVA, J. F. C.; CECON, P. R. Estimativas do valor energético a partir de características químicas e bromatológicas dos alimentos. Revista Brasileira de Zootecnia, Viçosa, MG, v. 30, n. 6, p. 1837-1856, 2001.

CARVALHO, P. C. F. A estrutura da pastagem e o comportamento ingestivo de ruminantes em pastejo. In: SIMPÓSIO SOBRE AVALIAÇÃO DE PASTAGENS COM ANIMAIS, 1997, Maringá. Anais... Maringá: UEM, 1997. p. 25-52.

CHAMPION, R. A.; ORR, R. J.; PENNING, P. D.; RUTTER, S. M. The effect of the spatial scale of heterogeneity of two herbage species on the grazing behaviour of lactating sheep. Applied Animal Behaviour Science, Edinburgh, v. 88, n. 1-2, p. 61-76, 2004.

COSTA, J. V.; OLIVEIRA, M. E.; MOURA, R. M. A. S.; COSTA JÚNIOR, M. J. N.; RODRIGUES, M. M. Comportamento em pastejo e ingestivo de caprinos em sistema silvipastoril. Revista Ciência Agronômica, Fortaleza, v. 46, n. 4, p. 865-872, 2015.

EMPRESA BRASILEIRA DE PESQUISA AGROPECUÁRIA - EMBRAPA. Sistema Brasileiro de Classificação de Solos. Rio de Janeiro: EMBRAPA Solos, 1999. $421 \mathrm{p}$. 
GAZDA, T. L.; PIAZZETTA, R. G.; DITTRICH, J. R.; MONTEIRO, A. L. G.; THOMAZ-SOCCOL, V. Distribution of nematode larvae of sheep in tropical pasture plants. Small Ruminant Research, Arkansas, v. 82, n. 2-3, p. 94-98, 2009.

GONÇALVES, E. N.; CARVALHO, P. C. F.; KUNRATH, T. R.; CARASSAI, I. J.; BREMM, C. FISCHER, V. Relações planta-animal em ambiente pastoril heterogêneo: processo de ingestão de forragem, Revista Brasileira de Zootecnia, Viçosa, MG, v. 38, n. 9, p. 1655-1662, 2009.

GORDON, H. M.; WHITLOCK, H. V. A new technique for counting nematode eggs in sheep faeces. Journal of the Council for Scientific and Industrial Research, Melbourne, v. 12, n. 1, p. 50-52, 1939.

GOVERNO DO ESTADO DO MARANHÃO. Gerência de planejamento e desenvolvimento econômico. Universidade Estadual do Maranhão. Atlas do Maranhão. São Luis: GEPLAN, 2002. 39 p.

HAILE, A.; TEMBELY, S.; ANINDO, D. O.; MUKASA-MUGERVA, E.; REGE, J. E. O.; YAMI, A.; BAKER, R. L. Effects of breed and dietary protein supplementation on the responses to gastrointestinal nematode infections in Ethiopian sheep. Small Ruminant Research, Arkansas, v. 44, n. 3, p. 247-261, 2002.

IGARASHI, M.; CARVALHO, D. G.; BUCCI, F. C.; MIRANDA, Y.; RODRIGUES, Z. M.; ALMEIDA, M. C. F.; PIONA, M. N. M. Efeito do neem (Azadirachta indica) no controle de nematódeos gastrintestinais em ovinos suplementados a pasto no período seco. Semina: Ciências Agrárias, Londrina, v. 34, n. 1, p. 301-310, 2013.

INFOSTAT ® SOFTWARE. Programa estatístico. Versión 2004. Córdoba: Universidad Naciona de Córdoba, 2004.

KÖSTER, H. H.; COCHRAN, R. C.; TITGEMEYER, E. C.; VANZANT, E. S.; ABDELGADIR, I.; ST-JEAN, G. Effect of increasing degradable intake protein on intake and digestion of low-quality, tallgrass- prairie forage by beef cows. Journal of Animal Science, Champaign, v. 74, n. 10, p. 2473-2481, 1996.

MANERA, D. B.; VOLTOLINI, T. V.; YAMAMOTO, S. M.; ARAÚJO, G. G. L.; SOUZA, R. A. Desempenho produtivo de ovinos em pastejo suplementados com concentrados contendo coprodutos do processamento de frutas. Semina: Ciências Agrárias, Londrina, v. 35, n. 2, p. 1013-1022, 2014.
PALHANO, A. L.; CARVALHO, P. C. F.; DITTRICH, J. R.; MORAES, A.; SILVA, S. C.; MONTEIRO, A. L. G. Características do processo de ingestão de forragem por novilhas holandesas em pastagens de capim-monbaça. Revista Brasileira de Zootecnia, Viçosa, MG, v. 36, n. 4, p. 1014-1021, 2007.

NOGUEIRA, D. M.; VOLTOLINI, T. V.; MOREIRA, J. N. Efeito da suplementação proteica sobre os parâmetros clínicos e parasitológicos de cordeiros manditos em pastagem de tifton 85. Ciência Animal Brasileira, Goiânia, v. 10, n. 4, p. 1107-1116, 2009.

OLIVEIRA, P. T. L.; TURCO, S. H. N.; VOLTOLINI, T. V.; ARAÚJO, G. G. L.; PEREIRA, L. G. R.; MISTURA, C.; MENEZES, D. R. Respostas fisiológicas e desempenho produtivo de ovinos em pasto suplementados com diferentes fontes proteicas. Revista Ceres, Viçosa, MG, v. 58, n. 2, p. 185-192, 2011.

PARENTE, H. N.; ZANINE, A. M.; SANTOS, E. M.; FERREIRA, D. J.; OLIVEIRA, J. S. Comportamento ingestivo de ovinos em pastagem de tifton-85 (Cynodon ssp) na Região Nordeste do Brasil. Revista Ciência Agronômica, Fortaleza, v. 38, n. 2, p. 210-215, 2007.

PHENGVICHITH, V.; LEDIN, I. Effect of a diet high in energy and protein on growth, carcase characteristics and parasite resistance in goats. Tropical Animal Health and Production, Edinburgh, v. 39, n. 1, p. 59-70, 2007.

RAYNAULD, J. P.; GRUNER, L. Feasibility of herbage sampling in large extensive pastures and availability of cattle nematode infective larvae in mountain pastures. Veterinary Parasitology, Uberaba, v. 10, n. 1, p. 57-64, 1982.

SELBACH, J. F.; LEITE, J. R. S. A. Meio ambiente no Baixo Parnaiba: olhos no mundo, pés na região. São Luis: EDFUMA, 2008. 216 p.

STEVALE, G. T. S.; CORREA, L.; CAMILO, D. J.; MAZZON, F.; MENDONCA, L. N. Avaliação de dois princípios ativo no controle de verminose em cordeiros naturalmente contaminados com H. contortus e Trichostrogylus spp. Synergismus scyentifica, Pato Branco, v. 11, n. 1, p. 82-85, 2016.

SILVA SOBRINHO, A. G. Produção de cordeiros em pastagens. In: SIMPÓSIO MINEIRO DE OVINOCULTURA. PRODUÇÃO DE CARNE NO CONTEXO ATUAL, 2001, Lavras. Anais... Lavras: Editora UFLA, 2001. p. 63-97.

TAYLOR, E. L. Technique for the estimation of pastures infestation by strongyle larvae. Parasitology, Cambridge, v. 31, n. 1, p. 473-478, 1939. 
VAN SOEST, P. J.; ROBERTSON, J. B.; LEWIS, B. A. Methods for dietary fiber neutral detergent fiber, and no starch polysaccharides in relation to animal nutrition. Journal of Dairy Science, Champaign, v. 74, n. 12, p. 3583-3597, 1991.

VELOSO, C. F. M.; LOUVANDINI, H.; KIMURA, E. A.; AZEVEDO, C. R.; ENOKI, D. R.; FRANÇA, L. D.; McMANUS, C. M.; DELL'PORTO, A.; SANTANA, A. P. Efeitos da suplementação proteica no controle da verminose e nas características de carcaça de ovinos Santa Inês. Ciência Animal Brasileira, Goiânia, v. 5, n. 3, p. 131-139, 2004.
WALLACE, D. S.; BAIRDEN, K.; DUNCAN, J. L.; ECKERSALL, P. D.; FISHWICK, G.; HOLMES, P. H.; MCKELLAR, Q.; MITCHELL, S.; MURRAY, M.; PARKINS, J. J. The influence of increased feeding on the susceptibility of sheep to infection with Haemonchus contortus. Journal of Animal Science, Champaign, v. 69, n. 2, p. 457-463, 1999.

WILLIS, H. H. A simple levitation method for the detection of hookworm ova. Medical Journal of Australia, Melbourne, v. 2, n. 18, p. 375-376, 1921. 